\title{
Carcinoma Scrotum- Two Case Reports and Review of Literature
}

\author{
*Dr. Alok Mohan, **Dr Shruti Singh, ***Dr. Swarn Kaur, \\ ****Dr. Veena K. Sharma \\ * Assistant Professor, Department Of Pathology, Muzaffarnagar Medical College, Muzaffarnagar U.P. 251203. \\ ** Assistant Professor, Department Of Pathology, Muzaffarnagar Medical College, Muzaffarnagar U.P. \\ 251203. \\ ***Professor, Department Of Pathology, BPS Govt.Medical College Khanpur Kalan. Sonepat Haryana \\ **** Professor, Department Of Pathology, Muzaffarnagar Medical College, Muzaffarnagar U.P. 251203.
}

\begin{abstract}
Scrotal carcinoma is a rare tumor. We report two cases of this rare tumor.
First case, a 40 year male, presented with a non-healing ulcer at the upper part of scrotum on right side, which did not respond to routine therapy. Patient had this ulcer for last five months. He had been a worker at automobile work-shop for last fifteen years and a chronic smoker for two decades. Scrotal skin was excised and sent for histopathology. It was reported to be as squamous cell carcinoma. This was likely due to a repeated occupational exposure outcome.

Second case was of a 38 year male presented with a cauliflower like growth at the upper part of scrotum on right side, which did not respond to therapy. Patient had this growth for last eight months. He is a chronic smoker for last 25 years. He had no significant occupational history. The patient underwent fine needle aspiration cytology and was reported to be squamous cell carcinoma with marked tumor diathesis.

After literature review, we conclude that scrotal carcinoma is currently a rare tumor, and even more in cases with occupational exposure to carcinogens. These case reports highlight the importance of proper history taking regarding occupation, smoking etc.
\end{abstract}

Key words: scrotal carcinoma, fine needle aspiration cytology, histopathology, occupational cancer

\section{Introduction}

The scrotum is a seven layer structure that invests the testes, adnexa, and distal spermatic cord. The seven layers are the epidermis, dermis, tunica dartos, three layers of Colle's fascia and the parietal layer of tunica vaginalis. ${ }^{1}$ Tumors have been reported to arise out virtually from any of the components of the scrotal wall. ${ }^{2}$ The incidence of scrotal malignancies is extremely low. ${ }^{3}$

Squamous cell carcinoma is the most common malignant tumor of the scrotum; however, rare cases of basal cell carcinoma, melanoma, Paget's disease and sarcoma have been reported. ${ }^{4}$ Squamous cell carcinoma of the scrotum is extremely rare in the general population. ${ }^{5}$ Squamous cell carcinoma of the scrotum was the first malignancy linked to occupational exposure. ${ }^{6}$ Previously, it most commonly resulted from exposure to environmental carcinogens such as chimney soot, tars, paraffin, and some petroleum products. Currently most cases result from poor hygiene and chronic inflammation. ${ }^{4}$ Used engine oils have elevated polycyclic aromatic hydrocarbons which tend to be greater for petrol engines than for diesel engine. Prolonged and repeated contact with such oils can cause skin and scrotal cancer. Car mechanics are at potential risk from used engine oil. ${ }^{7}$ The overall survival rate is worse in patients with squamous histological subtype, compared with other subtypes of scrotal cancer. ${ }^{8}$

Typically scrotum carcinoma occurred in the sixth decade of life, presenting with a visible skin lesion, slow-growing and painless nodule. ${ }^{9}$ Wide local excision with bilateral ilioinguinal lymphadenopathy is treatment of choice, with more limited surgery advocated in early cases. ${ }^{10}$ Prognosis correlates with the extent of nodal involvement. ${ }^{11}$ Only $25 \%$ of inguinal nodes at presentation are metastatic. ${ }^{12}$

In this article, we report two cases of carcinoma scrotum.

\section{Case Report 1-}

A 40 year male presented at surgical out- patient department of Muzaffarnagar Medical College and Hospital on October 2013, with a non-healing ulcer at the upper part of scrotum on right side, which did not respond to antibiotic therapy. Patient had this ulcer for last five months. He had no history of sexually transmitted disease or trauma in the scrotal area. He is a chronic smoker for last 20 years. He had been a worker at automobile work-shop for last fifteen years. He used to wash his work-outfits infrequently. His trousers and undergarments also get soiled by engine oil quiet frequently. He had no history of previous radiotherapy. 
Physical examination findings showed an oval-shaped, ulcerated-bleeding lesion on the right side of the scrotum, measuring $4 \times 3 \mathrm{~cm}$ in size, and $1.5 \mathrm{~cm}$ in depth. The ulcer was within the skin. No palpable lymph node was appreciated. Patient had many small sebaceous cysts all over the scrotum.

The patient underwent wide local excision of the skin lesion with a $2-\mathrm{cm}$ margin of normal tissue. The tumor of the scrotum was not adherent or infiltrative into the testis. But the lymph nodes were adherent to the surrounding tissues. Tissues excised were submitted to histopathological examination.

Gross findings showed skin covered piece of tissue measuring 5.0x4.0x2.0 cm, with hair follicles and many sebaceous cysts. On cut section, solid white- yellow areas were seen. (Image 1)

Microscopic examination of the tissue showed an ulcerated area of dysplastic stratified squamous epithelium. The sub-epithelial area showed atypical cells which are large, pleomorphic with hyperchromatic nuclei. At places islands of squamous cells with few keratin pearls are seen. There was infiltration of inflammatory cells, mainly lymphocytes, plasma cells, eosinophils and neutrophils. All margins and base were involved.

The diagnosis was well differentiated squamous cell carcinoma. (Image 2)

\section{Case Report -2}

A 38 year male presented at surgical out- patient department of Muzaffarnagar Medical College and Hospital in April 2014, with a cauliflower like growth at the upper part of scrotum on left side, which did not respond to therapy. Patient had this growth for last eight months. He had no history of sexually transmitted disease or trauma in the scrotal area. He is a chronic smoker for last 25 years. He had no significant occupational history.

Physical examination findings showed an exophytic growth, partly ulcerated-bleeding lesion on the right side of the scrotum, measuring $5 \times 4 \mathrm{~cm}$ in size. The growth was within the skin. Palpable lymph node was appreciated in ipsilateral inguinal region. The other significant finding was that the hygienic condition was bad. (Image 3)

The patient underwent fine needle aspiration cytology and was reported to be squamous cell carcinoma with marked tumor diathesis. (Image 4)

As the patient approached medical advice in a very late stage, surgery was not recommended and the patient was referred for specialized oncology center.

\section{Discussion}

Scrotal carcinoma is currently a rare tumor, and even more in cases with industrial exposure to carcinogens. ${ }^{13}$ It has long been recognized that the majority of cases are related to occupational exposure. It was first described in 1775 by Percival Pott when he observed an increased incidence of scrotal carcinoma in boys working as assistants to chimney sweeps. ${ }^{14}$

Pott correctly deduced that the prevalence of cancer of the scrotum among chimney sweeps was associated with "a lodgement of soot in the rugae of the scrotum". This was probably the first suggestion of the association of "substances" in the environment with the development of cancer in a particular occupational group. ${ }^{15}$

Scrotal carcinoma was the first malignancy to be definitely linked to a carcinogen in the work-place. Prolonged exposure to distillates of coal and mineral oils is also associated. ${ }^{6}$ The carcinogenic properties of mineral oils are linked to their content of polyaromatic hydrocarbons, which are present as contaminants. ${ }^{16}$ Engine oils have elevated polycyclic aromatic hydrocarbon content with use; prolonged and repeated contact with used engine oil can cause skin and scrotal cancer. Car mechanics are at potential risk from used engine oil. $^{17}$

Few studies have correlated squamous cell carcinoma with oncogenic human papilloma viruses, but a direct causal relationship has not been derived. ${ }^{18}$ Patients usually delay in approaching the doctor. This may be due to embarrassment, ignorance or both. ${ }^{6}$

Squamous cell carcinoma of scrotum frequently present as a solid wart or nodule on the scrotum. Superficial ulceration may follow increase in size or the effect of scratching at the lesion. Ulcerated lesions may have a sero-sanguinous discharge. There may be ipsilateral or bilateral inguinal lymph node enlargement which may be inflammatory or neoplastic or both. Iliac nodes may be involved when there is no recognized inguinal involvement. Carcinoma scrotum tends to remain localized to the scrotal wall. Distant spread is rare. ${ }^{19}$ Testicular and penile involvement has been reported. ${ }^{19}$

Besides the general investigations, the diagnosis is to be confirmed by biopsy of the edge of the scrotal lesion. There remains a need for the extensive evaluation for finding out the disease extension. Abdominoperineal ultrasound, MRI of the scrotum and chest CT is desirable. ${ }^{19}$

Ray and Whitmore ${ }^{19}$ have proposed staging of scrotal carcinoma.

○ STAGE A 
- Disease localized to the scrotum

- Locally extensive disease involving adjacent structures (penis, perineum, testis and/or cord structures, pubic bone) by continuity but without evident metastasis.

- STAGE B

- Regional metastasis, resectable

- STAGE C

- Regional metastasis, non- resectable

- STAGE D

- Distant metastasis (beyond regional nodes)

Treatment includes wide excision with a 2-3 cm margin. Surrounding sub-cutaneous tissue should be excised with the primary tumor. Resection of scrotal contents is rarely necessary.

\section{Conclusion}

To conclude, scrotal carcinoma is now a rare entity. Early medical opinion is beneficial. Awareness in our environment of the existing disease will definitely improve the index of suspicion among practicing surgeons, oncologists and patients.

\section{References}

[1]. Rosai J. Rosai and Ackerman's Pathology, London. Mosby. (tenth edition) 20011:1383-1398.

[2]. Rowland RG, Herman JR. Tumors and infectious diseases of the testis, epididymis, and scrotum. In: Gillenwater JY, Grayhack JT, Howards SS, Mitchell ME, editors. Adult and pediatric urology. Philadelphia: Lippincott, Williams and Wilkins; 2002.

[3]. Chamorro JC, Garcia SG, de Blas Gomez V. Scrotal carcinoma. Arch Esp Urol. 2011; 64:541-543.

[4]. Presti JC ., Jr. Genital tumors. In: Tanagho Ea, McAnich JW,editors. Smith's General Urology. New York: McGraw Hill; 2008.pp.75-87.

[5]. Castiglione FM, Selikowitz SM, Diamond RL. Mule spinner's disease.Arch Dermatol 1985, 121:370-372.

[6]. Waldron HA. A brief history of scrotal cancer. Br J Ind Med. 1983; 40:390-401.

[7]. Health and safety fact sheet-No.12 Wyre Borough Council; Lancashrie U.K.:2002. Available from: http://www.wyrebc.gov.uk.

[8]. Wight JL, Man TM, Lin DW. Primary scrotal cancer: disease characterstics and increasing incidence. Urology. 2008;72:1139-1143.

[9]. Andrews PE, Farrow GM, Oesterling JE. Squamous cell carcinoma of scrotum: longterm follow-up of 14 patients. J Urol. 1991; 146:1299-1304.

[10]. Lowe FC. Squamous cell carcinoma of scrotum.Urology 1985, 25:63-65.

[11]. Jerome E A. A review of the history, epidemiology and treatment of squamous cell carcinoma of the scrotum.(abstract) Rare tumors. 2009 July 22;1(1):e17.11

[12]. Wei P, Guosheng F, Heming L, Chen J,Chen K, Hao Y, and Cao Y. A case report of scrotal carcinoma and review of the literature. Case Rep Oncol. 2012 May-Aug; 5(2):434-438.

[13]. Casacola Chamorro J, Gutierrez Garcia S, de Blas Gomez V. Scrotal carcinoma (abstract). Arch Esp Urol. 2011 Jul ;64(6):541-3.

[14]. Pott P. Chirurgical observations relative to the cataract, the polypus of the nose, cancer of the scrotum, different types of the ruptures, and the modification of the toes and feet. London, UK: Hawes, 19775:1-208.

[15]. Sarah Saunders, Julie Martin, and Dean Harmse. Scrotal carcinoma: a reminder of a disappearing occupational disease. BMJ Case report. 2009;2009:bcr06.2008.0132

[16]. IARC Overall evaluations of carcinogenicity: an updating of IARC monographs volumes 1 -42. IARC Monographs 1987 ;(suppl 7):252.

[17]. Wyre Borough Council, Lancashire, U.K., Carcinogens.[(cited $5^{\text {th }}$ July, 2008)]; in Health and safety factsheet-No 12 (internet)2002. Available from http;/www.wyrebc.gov.uk.

[18]. Orihuela E, Tyring S.K, Pow-sang M, et al. Development of Human Papilloma virus type 16 associated with squamous cell carcinoma of the scrotum in a patient with Darier's disease treated with systemic iso-retinoin. J Urol.1995; 153:1940-3.

[19]. Ray B, Whitmore Wf., Jr Experience with Carcinoma of the scrotum. J Urol.1977; 117:741-5.

\section{Images}

Image 1- Excised Scrotal Wall Of (Case 1)

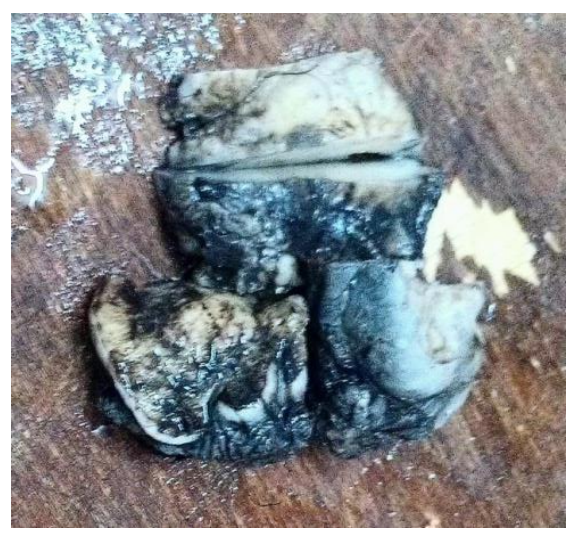


Image 2- HISTOPATHOLOGY H\&E 40X (CASE1)

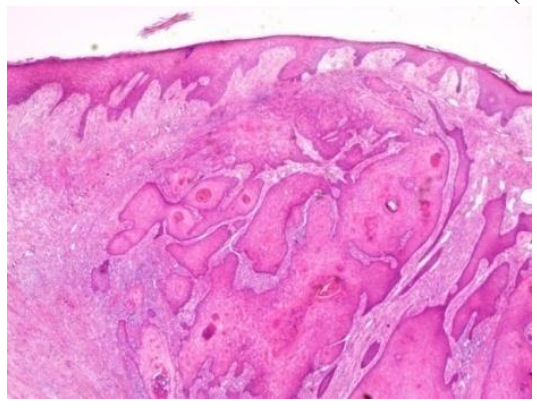

Image3- Clinical Microphotograph Of Case 2

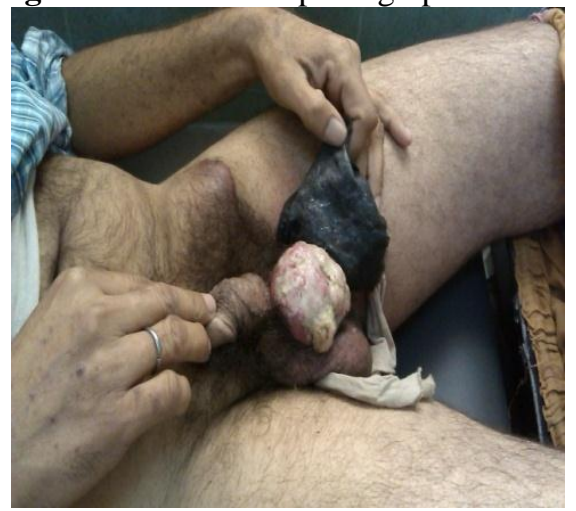

Image 4- Fnac Image Of Case 2 (Mgg 40x)

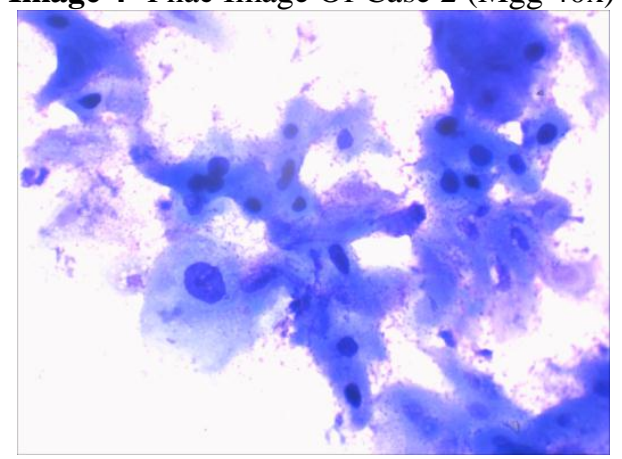

